\title{
Reflections on the Theme Education of "Remaining Faithful to Our Original Aspiration and Keeping Our Mission Firmly in Mind" in Jiangxi Province
}

\author{
Zhao Kun \\ The Party School of CPC Nanchang Municipal Committee
}

Keywords: remain faithful to our original aspiration; keep our mission firmly in mind; rule the Party in an all-round and strict manner

\begin{abstract}
Remaining Faithful to Our Original Aspiration and Keeping Our Mission Firmly in Mind" embody the consistent political feature and character of the Party. Carrying out the theme education is an inevitable requirement for us to consolidate the achievements of ruling the Party in an all-round and strict manner since the 18th National Congress of CPC, to continuously self-purify, self-enhance, self-renovate and self-improve our Party, and to realize the strategic goal of "Two Centenary Goals". While the report 19th CPC National Congress has stated positively that "stay true to the mission”, a series of further understanding have emerged.
\end{abstract}

\section{Understanding of the Theme Education}

The reports of 19th National Congress of CPC pointed out that focusing on leading cadres at and above the country level, we should launch the theme education of "Remaining Faithful to Our Original Aspiration and Keeping Our Mission Firmly in Mind" in the whole Party, arm ourselves with the Party's new theories and push the whole party to strive more consciously for the realization of historical mission of the Party in the new era. Here are "three necessary requirements".

Since the 18th National Congress, full and strict governance over the Party started with the implementation of Eight Regulations of the Central Committee. It focused on specific issues such as "a waste of food", "unhealthy practices in clubs", "extravagance in traffic" and "corruption in festivals.” On Tuesday (December 12), General Secretary Xi pointed out in an article that It is impossible for us to stop correct undesirable work styles, and the construction of work style is always on the road". At the same time, from some reported cases and Confessions, we can see that many people turned to be "prisoners" from the "pride" of their family members and the capable in the eyes of the masses. This is because to a large extent, they have forgotten the "initial mind" and where they came from.

Recalling the history of our Party's development, we have carried out different corresponding thematic educations in different periods with the purpose of continually strengthening our Party's self-construction. Since the 18th National Congress, our Party has successively launched practical activities of mass line education, special topic education of Three Stricts and Three Earnests and "Two Studies, One Action". The Party's practice of mass line education begins with the implementation of eight regulations, focusing on four undesirable work styles; "Three Stricts and Three Earnests" special education is an extension and deepening of the mass line education, and its emphasis is political discipline and rules; "Two Studies and One Action" stresses the combination of learning and doing. Subject education focuses on different issues, so the objects and emphases are also different.

Since the founding of CPC, it has historical missions in every period. To realize national rejuvenation is the greatest dream of Chinese nation in modern times. After a glorious course of 96 years, standing at the intersection of "Two Hundred Years", Our Party carries out the theme education. The sentence of "Remaining Faithful to Our Original Aspiration" means that no matter how far you go, you can't forget the past and why you set out, always keeping a true heart". The sentence of "Keeping Our Mission Firmly in Mind" refers to that we must always maintain the fighting spirit of Chinese Communists when the Party was founded and firmly build the confidence of realizing the great rejuvenation of Chinese nation when facing the future as well as challenges. 


\section{Key Problems in the Theme Education}

In times of peace with very abundant materials, it is impossible for us to return to hard times of the past. Therefore, the theme education must firmly hold onto the general switch of thoughts, and inherit the spirit of struggle, fighting and dedication in that era. As for the theme education, some grassroots cadres fail to have enough understanding, among who, some paying close attention regard it as sports while some lacking concern take it just as a formality. Through theme education, we should further solve some problems such as some Party members and cadres are indifferent to their ideals, have unsteady beliefs, divorce from the masses, have a weak sense of right and wrong, lack principles and some new hidden problems appearing in dealing "four undesirable work styles".

In the 19th National Congress, Amendment to the Party Constitution has been approved and Xi Jinping 's Thought of Socialism with Chinese Characteristics in a New Era is regarded as part of the Party's guide for action. This has realized another advance of the Party's guiding ideology to keep pace with the times again. Focusing on new missions requires new ideas to guide the overall struggle, great project, great cause, great dream, secure a decisive victory in building a moderately prosperous society in all respects, and strive for the great success of socialism with Chinese characteristics in the new era. All of these ask us to arm the whole Party with the latest theoretical achievements, guide the practice and promote work.

It is necessary to vigorously carry forward the good academic atmosphere of integrating theory with practice, focus on people-centered thoughts of developing, goals of "Two Hundred Years" and the great Chinese Dream of national rejuvenation. We must achieve the target of building a moderately prosperous society in all respects in 2020 and make China become a modern socialist country before $100^{\text {th }}$ anniversary. For leading cadres, they are required to be loyal to the Party, keep incorruptible, dare to assume responsibility, focus on improving abilities in all aspects, and strive to create new achievements that can stand up to the test of practice, people and history.

\section{Suggestions on the Methods, Steps and Procedures for Carrying out the Theme Education}

Since the 18th National Congress, our Party has successively launched education activities such as "practical activities of mass line education", special topic education of Three Stricts and Three Earnests and "Two Studies and One Action". These concentrated education activities have achieved remarkable results. First, the construction of work style has been taken as a major and urgent task; second, the problem of "four undesirable work styles" has been solved centrally; third, leading organs, groups and cadres have been regarded as the focal points of solving problems; fourth, we pay more attention to the establishment of long-term effective mechanisms. But at the grass-roots level, there are inevitably some problems such as "formality" of activities, a lack of attraction and poor effectiveness. In the upcoming theme education, we need conscientiously sum up the good experience of the past, face up to the problems that still exist, arm the brains with the Party's innovative theories, and achieve practical results.

Recently, the General Secretary Xi led the Standing Committee of the Political Bureau of Central Committee to make a special trip to pay tribute to the site of the First Congress of CPC in Shanghai and the red vessel of South Lake in Jiaxing, Zhejiang, for reviewing the founding history and relive the Party joining oath which has made a good demonstration to the innovative learning of grass-roots. When we carry out similar activities, the participation rate of Party members and cadres is also very high. Therefore, we hope this theme education can be more similar to "live teaching" "experience teaching" "situation teaching" and other forms to enhance the attractiveness of education. For example, in order to solve the problem of single form, we can enhance the attractiveness of by organizing Party anniversary, seminars, lectures, exams, debates, speeches, outings and visits, and theatrical performances. We also should help Party members and cadres to awaken their original aspirations and find the very beginning minds by retrieving the Party membership introduces and recalling the circumstances of joining the Party. In view of the fact that ordinary Party members at the grassroots level have a low theoretical level, we can make learning and education truly into their mind by recording some fresh and lively learning materials such as 
audio, video, micro-film, and "three and a half sentences".

We should integrate the theme education into the "Two Studies and One Action" education which will be made as a big framework. Its learning and education are promoted in two aspects: The theme education will be launched for officials at and above the county and director level; for those who are below the county level, education will be based on "Two Studies and One Action", incorporating the relevant requirements, adhering to the latest requirements of the 19th National Congress' spirit, and joining new connotations.

\section{Matters in the Process of Carrying Out the Theme education}

In the article entitled "New Manifestations of Formalism and Bureaucracy Deserve Vigilance" of Xinhua News Agency, General Secretary Xi requires that we should abstain from formalism and ensure good effects with good style in the forthcoming theme education.

In the process of theme education, we should not only distinguish ordinary Party members from leading cadres at different levels, but also make a clear distinction between the situation of Party organizations and members in different industries and fields. It is unwise to try to attend to big and small matters all at once. In the opposite, we must draw a "standard image", put forward specific parameters, and tell others "how to learn and learn what". Only in this way can we promote the theme education step by step, let every Party member receive education.

It is necessary to closely integrate the actual situations in our region, give prominence to the key points, correctly select breakthrough points, and adhere to the principle of "solve whatever problems you have and focus on what problems you focus on". Through "wall chart combat" and "special topic investigation", we will try our best to solve key problems that affect and restrict the work. On issues related to institutional mechanisms, we should boldly emancipate our minds and blaze new trails. With regard to the issues involving multiple departments and units, it is important to actively explore effective ways to interact with each other and to solve problems in a coordinated manner so that results of theme educational activities will not be discounted and effects be achieved.

Party organizations at all levels need to give prominence to actual results, stress forms like intensive discussions, individual inquiries, and visits to the masses, grasp the effects of theme education carried out by the grass-roots Party organizations, and listen to the opinions and evaluations made by grass-roots Party members and the masses. It is suggested to simplify certified information. When inspecting the information of grass-roots Party organizations at all levels, it is necessary to change the "trace doctrine" used in the inspection work in the past, reduce unnecessary sorting of Party-building materials and avoid becoming "material education" and "account books education".

\section{Practical Paths of the Theme Education}

To grasp the theories arming work is the primary task of ideological construction. For example, by integrating the theories arming work into Party-building brand activities such as home visits and Sunshine Post Road, Nanchang promotes the study and dissemination of theories with flexible preaching.

At present, in combination with the 19th National Congress, all districts and counties in Nanchang take the initiative to explore the thematization and objectify of home visits, and aim at giving it a new meaning. "Visiting style" dissemination has been carried out. Nanchang clearly demands that all cadres should go to rural villages and street communities where they hang down, join hands with the needy, engage with ordinary Party members to disseminate the spirit of the 19th National Congress, and thoroughly understand the wishes of the masses. A "menu style" dissemination has also been carried out. We have organized 200 backbone speakers and make up 16 tour propaganda groups.

In order to help enterprises to solve difficulties, we have founded "one on one "contact service green Channel-Sunshine Post Road. While helping enterprises solve practical difficulties, we insist 
on holding the Party's thoughts and beliefs throughout the entire process. After several years, these large enterprises have expanded to small and medium-sized enterprises, achieving full coverage and accessing to the enterprises' praise. Since the 19th National Congress, Nanchang has organized enterprises through the platform of "Sunshine Post Road" to carry out the study and education activities of "Celebrating the 19th Congress and Walking with the Party Forever" as well as held special lecture presentations on "The Spirit of the 19th National Congress of the CPC".

\section{References}

[1] Wang Xuebing. On the Construction of the Advanced Nature of CPC from the Perspective of "Remaining Faithful to Our Original Aspiration and Keeping Our Mission Firmly in Mind" [J]. Journal of Zhuhai Institute of Administration, Zhuhai Municipal Party School of CPC [J], 2017, $12: 20-25$.

[2] Sun Zhengyu. Scientific Understanding of the Truth of Marxism [J]. Seeking Truth, 2016-3-31(07): 13.

[3] Xi Jinping. Speech at the Symposium on the Work of Philosophy and Social Science [N]. People's Daily, 2016-05-19 (First Edition).

[4] Xi Jinping. Secure A Decisive Victory in Building a Moderately Prosperous Society in All Respects and Strive for the Great Success of Socialism with Chinese Characteristics in the New Era-the Report at the 19th National Congress of CPC [M]. Beijing: People's Publishing House. 